\title{
ENTREPRENEURIAL CHARACTERISTICS ARE VIEWED FROM SELF EFFICACY FOR ENTREPREUNEURS IN HARAPAN ISLAND
}

\author{
Kania Ratnasari \\ Sahid University \\ kania.ratnasari@yahoo.com
}

\begin{abstract}
The purpose of this study was to determine the profile of entrepreneurs in Harapan Island, then to find out the entrepreneurial characteristics and self-efficacy of business actors in Harapan Island. The distribution of questionnaires on entrepreneurial characteristics and self-efficacy was given to 40 entrepreneurs on Harapan Island. The data analysis used is quantitative descriptive analysis, Tabulation Data, Data Display and Conclusion Drawing. The results of this study are the majority of women entrepreneurs aged 44-50 years with an educational background, namely junior high. Then, the overall entrepreneurial characteristics included in the high category with the highest indicator, Need for Achievement and the lowest indicator, Propensity to Take Risk. As for overall self-efficacy, it is categorized as very high with the highest indicator being Strength and the lowest indicator being Generality.
\end{abstract}

Keywords: Entrepreneurship Characteristics, Self-Efficacy, Harapan Island, Business Actors, Tourism

\section{INTRODUCTION}

Micro, Small and Medium Enterprises (MSMEs) are one of the supporters of economic growth in Indonesia, this can be seen from the existence of significant small businesses, both from the traditional and modern sectors through micro small and medium enterprises (MSMEs). Many independent businesses run by the middle to lower class have a fairly good role in running the Indonesian economy. SMEs can absorb labor while also being able to increase community income. This means that MSMEs can be considered to have a fairly good role in reducing poverty and unemployment in Indonesia (Isa, 2011).

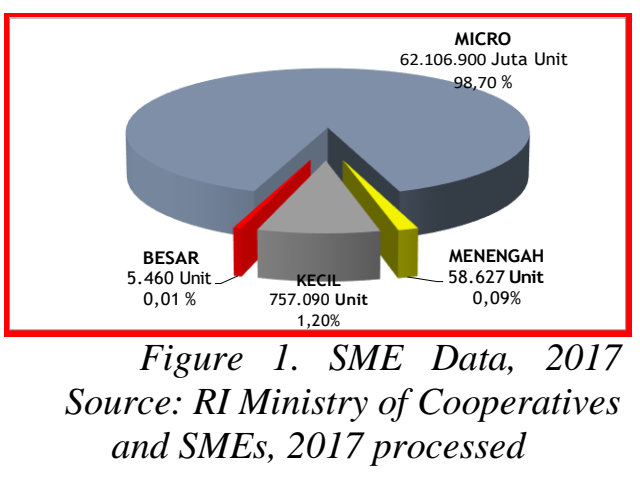

Based on data from the Ministry of Cooperatives and SMEs of the Republic of Indonesia regarding business unit statistics in Indonesia, it can be seen in 2017 that the total number of MSMEs is 63 million business units or $99.9 \%$ of the 
total business units that exist in Indonesia.

One of the MSMEs in Indonesia is the MSME on Harapan Island. These SMEs are food vendors (catering), souvenir makers, ship owners and homestay owners. The SMEs are very dependent on the tourism potential and tourist arrivals who come to visit Harapan Island. President Joko Widodo is targeting 20 million tourists to come to Indonesia in 2019 where the Thousand Islands is one of the regions planned to contribute to meeting the target. Many residents of Harapan Island have switched professions to become business operators, such as by establishing homestays, becoming tour guides, renting boats that were originally used for fishing, then changing to take tourists to the destination.

These changes are not easy for the residents in Harapan Island. Confidence in the ability of business actors is still considered low to be able to change their circumstances. Included in terms of controlling their confidence in their ability to become entrepreneurs. Though self efficacy is an important basis and capital for someone who will become an

\section{LITERATURE REVIEW}

Many views can be found in a variety of literature but the most common things related to entrepreneurship include covering wealth creation, company creation, innovation creation, change creation, job creation, value creation, and growth creation (Kraus et al., 2012). Entrepreneurship is the ability of someone who has a creative and innovative side to be used as a basis, processes and resources in finding opportunities for profit, value creation, product or service fsee tormation and finally success. (Ardiansyah, 2017). entrepreneur to always be optimistic to move forward. Self efficacy can determine in taking an action or a decision to achieve the desired life goals. This self-confidence is most likely to influence the behavior and character of entrepreneurs. Touching on the characteristics of entrepreneurs on the Harapan Island certainly requires careful preparation both internally and externally to deal with changes in character for the future sustainability of the residents on Harapan Island.

The study of this research is expected to be able to find out what kind of characters exist in the people of Harapan Island so that they are able to compete in advancing the concept of tourism on Harapan Island, especially that it can be seen and reviewed from self-efficacy in order to achieve better life goals and creation the concept of advanced tourism on Harapan Island. The purposes of this research are 1) To find out the profile of entrepreneurs in Harapan Island, 2) To find out the characteristics of business people in Harapan Island and 3) To find out the self-efficacy of business operators in Pulau Harapan.

\section{Entrepreneurship Characteristics}

Entrepreneurial characteristics variable consists of 1) Locus of Control. This is the level where individuals believe that their achievement depends on their own behavior, 2) Propensity to Take Risk. This is a situation that has been calculated before by an entrepreneur to develop strategies and minimize the impact of the risks to be taken, 3) Selfconfidence. This is a high belief that someone is able to overcome the problem with the best situation, 4) Need for Achievement. These are individuals who are trying to excel to achieve success and the need for achievement in business development, 5) Tolerance to Ambiguity. This is the ability of individuals to 
respond positively to ambiguous situations, 6) Innovativeness. This is the existence of creativity and innovative ideas that are able to combine ideas with available resources to produce the final value (Ghina \& Ramadhan, 2017).

\section{Self-Efficacy}

In general, it can be said that entrepreneurship from the side of selfefficacy leads to an individual's trust in his ability in perform tasks and roles aimed at obtaining entrepreneurial results (Newman et al., 2019). Self-efficacy also explains a person's belief that he can perform tasks and fulfill roles, then directly related to expectations, goals, and motivation (Kerr et al., 2018). The difference in self-efficacy in each individual lies in three components, namely Magnitude, Strength, and Generality.

Each component of the Self-Efficacy has an important impact that can be more clearly explained as follows: 1) The level of difficulty of the task (Magnitude). This relates to a problem related to the degree of difficulty of individual tasks. This component impacts the selection of behavior that the individual will try based on expectations of efficacy through the difficulty of the task. Individuals who are in this component will try to do certain tasks that can be carried out and will avoid situations or behaviors beyond their ability; 2) The power of belief (Strength). This component is related to the strength of an individual's faith in his abilities. Individuals will be moved to achieve goals even though they may not yet have supporting experiences with the support of strong expectations otherwise the individual will be easily swayed by unsupportive experiences if supported by weak expectations and doubt about the ability of the individual's self; 3) Generality. This component is related to behavior where individuals feel confident about their abilities. Individuals can feel confident about their abilities, depending on their understanding of their abilities that are limited to a broader and varied set of activities and situations.

\section{RESEARCH METHOD}

The objects of this research are entrepreneurs who are in the Harapan Island environment with several criteria, namely a) Entrepreneurs living in Harapan Island and b) Active in running a business and owning a place of business

\subsection{Data Collection Techniques}

The data used in this study are primary data, where data is obtained directly, in this case through interviews and questionnaires regarding entrepreneurial characteristics and self-efficacy to entrepreneurs on Harapan Island.

\subsection{Operational Definitions of Variables}

Operational variables in the study consisted of entrepreneurial characteristics and self-efficacy. The indicators used for entrepreneurial characteristics variable are consists of 1) Locus of Control. This is the level where individuals believe that their achievement depends on their own behavior, 2) Propensity to Take Risk. This is a situation that has been calculated before by an entrepreneur to develop strategies and minimize the impact of the risks to be taken, 3) Selfconfidence. This is a high belief that someone is able to overcome the problem with the best situation, 4) Need for Achievement. These are individuals who are trying to excel to achieve success and the need for achievement in business development, 5) Tolerance to Ambiguity. This is the ability of individuals to respond positively to ambiguous situations, 6) Innovativeness. This is the existence of creativity and innovative 
ideas that are able to combine ideas with available resources to produce the final value

While the indicators used for selfefficacy are: 1) Magnitude. This relates to a problem related to the degree of difficulty of individual tasks; 2) Strength. This component is related to the strength of an individual's faith in his abilities; 3 ) Generality. This component is related to behavior where individuals feel confident about their abilities.

\subsection{Sample Collection Techniques}

This research used purposive sampling technique with special consideration so that it is suitable as a sample. The research sample consisted of 40 respondents from 120 respondents that recorded on Harapan Island who were present because only 40 respondents were present and were willing to serve as research respondents

\subsection{Data Analysis Techniques}

The data analysis used is quantitative descriptive analysis, Tabulation Data, Data Display and Conclusion Drawing.

\section{RESULTS AND DISCUSSION}

Below are the results and discussion seen from the respondent's profile, entrepreneurial characteristics and selfefficacy.

\section{Entrepreneur Profile}

The following below is a profile of respondents who are entrepreneurs in Harapan Island.

Tabel 1. Entrepreneur Profile

\begin{tabular}{|c|l|c|c|}
\hline Category & \multicolumn{1}{|c|}{ Indicator } & Amount & Percentage \\
\hline \multirow{4}{*}{ Age } & $<30$ years old & 3 & 7,5 \\
\cline { 2 - 4 } & $31-36$ years old & 10 & 25 \\
\cline { 2 - 4 } & $37-43$ years old & 6 & 15 \\
\cline { 2 - 4 } & $44-50$ years old & 13 & 32,5 \\
\cline { 2 - 4 } & $>50$ years old & 8 & 20 \\
\hline \multirow{4}{*}{ Gender } & Woman & 33 & 82,5 \\
\cline { 2 - 4 } & Man & 7 & 17,5 \\
\hline \multirow{4}{*}{ Last Education } & Elementary School & 12 & 30 \\
\cline { 2 - 4 } & Junior High School & 9 & 37,5 \\
\cline { 2 - 4 } & Senior High School & & \\
\cline { 2 - 4 } & Diploma & 4 & 10 \\
\cline { 2 - 4 } & Bachelor & & \\
\hline
\end{tabular}

Source: Data Processed (2020)

Profiles of respondents in entrepreneurship on Harapan Island can be seen in table 1 based on Age, Gender and Latest Education. In the Gender category, it turns out that women are more dominant as entrepreneurs on Harapan Island with a yield of $82.5 \%$. The next entrepreneurial profile is seen based on age, where age 44 years to 50 years dominates entrepreneurship in Harapan Island by $32.5 \%$ and the last entrepreneurial profile can be seen based on the latest education, where the majority of entrepreneurs are educated at $37.5 \%$ junior high and this is It was very apparent when distributing the 
questionnaire was carried out, there were some respondents who had difficulty filling out the questionnaire because they could not read well and or could not understand the statement given.

\subsection{Entrepreneurship Characteristics}

The following will be presented data on the responses of respondents regarding the characteristics of entrepreneurship based on 6 indicators are indicators, namely Locus of Control, Propensity to Take Risk, SelfConfidence, Need for Achievement, Tolerance to Ambiguity and Innovativeness. The following are respondents' responses to the characteristics of entrepreneurship.

Table 2. Respondents' Responses Regarding Entrepreneurial Characteristics

\begin{tabular}{|c|c|c|c|c|}
\hline No & Statements & Amount & Total Average & Category \\
\hline \multicolumn{5}{|c|}{ Locus of Control } \\
\hline 1 & Being a leader depends on ability & 170 & 4,25 & Very High \\
\hline 2 & $\begin{array}{l}\text { Most of what happens in life is } \\
\text { accidental }\end{array}$ & 114 & 2,85 & High Enough \\
\hline 3 & $\begin{array}{l}\text { Most of what happens in life is } \\
\text { determined by people in power }\end{array}$ & 153 & 3,82 & High \\
\hline 4 & Some friends depend on how good I am & 99 & 2,47 & Low \\
\hline 5 & $\begin{array}{l}\text { What will happen will definitely } \\
\text { happen }\end{array}$ & 200 & 5 & Very High \\
\hline 6 & $\begin{array}{l}\text { Life is controlled by others who are } \\
\text { stronger }\end{array}$ & 153 & 3,82 & High \\
\hline \multicolumn{3}{|c|}{ Average } & 3,70 & High \\
\hline \multicolumn{5}{|c|}{ Propensity to Take Risk } \\
\hline 1 & $\begin{array}{l}\text { Choose something that is low risk / has } \\
\text { high security rather than big profits that } \\
\text { are high risk }\end{array}$ & 186 & 4,65 & Very High \\
\hline 2 & Risk as a situation that must be avoided & 99 & 2,47 & Low \\
\hline 3 & $\begin{array}{l}\text { When it comes to making decisions } \\
\text { related to work, it's better to "play it } \\
\text { safe" }\end{array}$ & 132 & 3,30 & High Enough \\
\hline 4 & $\begin{array}{l}\text { Implement the plan when you are very } \\
\text { sure that it will run smoothly }\end{array}$ & 130 & 3,25 & High Enough \\
\hline 5 & $\begin{array}{l}\text { Prefer work that already knows the } \\
\text { problems in it even though the new job } \\
\text { offers greater benefits }\end{array}$ & 134 & 3,35 & High Enough \\
\hline \multicolumn{3}{|c|}{ Average } & $\mathbf{3 , 4 0}$ & High Enough \\
\hline \multicolumn{5}{|c|}{ Self-Confidence } \\
\hline 1 & $\begin{array}{l}\text { Anything is possible if you believe you } \\
\text { can do it }\end{array}$ & 189 & 4,72 & Very High \\
\hline 2 & $\begin{array}{l}\text { If you take on an assignment, you must } \\
\text { be sure you will succeed in doing it }\end{array}$ & 169 & 4,22 & High \\
\hline 3 & Do something always with all abilities & 170 & 4,25 & Very High \\
\hline
\end{tabular}

* Corresponding author's e-mail: kania.ratnasari@yahoo.com 


\begin{tabular}{|c|c|c|c|c|}
\hline No & Statements & Amount & Total Avarage & Category \\
\hline 4 & Success is a fortune & 119 & 2,97 & High Enough \\
\hline 5 & Whatever is done, it depends on us & 183 & 4,57 & Very High \\
\hline \multicolumn{3}{|c|}{ Average } & 4,14 & High \\
\hline \multicolumn{5}{|c|}{ Need for Achievement } \\
\hline 1 & $\begin{array}{l}\text { The desire to get the best results in } \\
\text { everything that is done }\end{array}$ & 200 & 5 & Very High \\
\hline 2 & $\begin{array}{l}\text { Take lessons from the failures } \\
\text { experienced }\end{array}$ & 196 & 4,90 & Very High \\
\hline 3 & $\begin{array}{l}\text { Give a challenge in the form of targets } \\
\text { for yourself when getting a new task }\end{array}$ & 174 & 4,35 & Very High \\
\hline 4 & $\begin{array}{l}\text { Take on easy tasks in order to be } \\
\text { satisfied with the results of the work }\end{array}$ & 172 & 4,30 & Very High \\
\hline 5 & $\begin{array}{l}\text { Has a tendency to put aside difficult } \\
\text { tasks and then do it later }\end{array}$ & 163 & 4,07 & High \\
\hline \multicolumn{3}{|c|}{ Average } & $\mathbf{4 , 5 2}$ & Very High \\
\hline \multicolumn{5}{|c|}{ Tolerance to Ambiguity } \\
\hline 1 & $\begin{array}{l}\text { Feel quite comfortable in a difficult } \\
\text { Situation }\end{array}$ & 82 & 2,05 & Low \\
\hline 2 & $\begin{array}{l}\text { After facing failure, can get up and start } \\
\text { over from the beginning }\end{array}$ & 172 & 4,30 & Very High \\
\hline 3 & $\begin{array}{l}\text { When facing difficulties, you can look } \\
\text { for other alternative solutions }\end{array}$ & 168 & 4,20 & High \\
\hline 4 & $\begin{array}{l}\text { Enjoy situations where there are rules } \\
\text { that must be respected }\end{array}$ & 176 & 4,40 & Very High \\
\hline 5 & $\begin{array}{l}\text { Often feel trapped in a difficult } \\
\text { Situation }\end{array}$ & 135 & 3,37 & High \\
\hline 6 & Difficulty in anticipation of obscurity & 123 & 3,07 & High Enough \\
\hline \multicolumn{3}{|c|}{ Average } & $\mathbf{3 , 5 6}$ & High \\
\hline \multicolumn{5}{|c|}{ Innovativeness } \\
\hline 1 & $\begin{array}{l}\text { Have a high curiosity and continue to } \\
\text { look for new discoveries }\end{array}$ & 175 & 4,37 & Very High \\
\hline 2 & Can see various solutions to a problem & 168 & 4,20 & High \\
\hline 3 & $\begin{array}{l}\text { Prefer to use the old way of doing } \\
\text { Things }\end{array}$ & 172 & 4,30 & Very High \\
\hline 4 & $\begin{array}{l}\text { Without having a lot of money we can } \\
\text { do many things }\end{array}$ & 178 & 4,45 & Very High \\
\hline \multicolumn{3}{|c|}{ Average } & 4,33 & Very High \\
\hline \multicolumn{3}{|c|}{ Overall Total Average } & 3,94 & High \\
\hline
\end{tabular}

Source: Data Processed (2020)

Based on table 2 can be seen the results of respondents' responses regarding entrepreneurial characteristics. Entrepreneurial characteristics consist of 6 indicators, namely Locus of Control, Propensity to Take Risk, Self-
Confidence, Need for Achievement, Tolerance to Ambiguity and Innovativeness. Entrepreneurial characteristics get a value of 3.94 including the high category with the highest indicator namely Need for 
Achievement of 4.52 , including the very high category while the lowest indicator is Propensity to Take Risk of 3.40 including the high enough category. Here it can be seen that at the highest indicator, namely Need for Achievement, in essence, entrepreneurs in Harapan Island hope for the achievement of all their businesses. The highest score is about the statement about wanting to get the best results in everything done, so whatever the entrepreneurs have done on Harapan Island, they want the best results for the sustainability of their business, while the lowest indicator is Propensity to Take Risk, in essence the entrepreneurs on Harapan Island do not dare or do not dare to take big risks, and even tend to avoid risk.

\subsection{Self-Efficacy}

The following will be presented respondent's response data on selfefficacy based on its indicators of 3 indicators, namely magnitude, strength and generality. Here are the responses of respondents to self-efficacy.

Table 3. Respondents' Responses Regarding Self Efficacy

\begin{tabular}{|l|l|c|c|c|}
\hline No & \multicolumn{1}{|c|}{ Statements } & Total & Total Average & Category \\
\hline \multicolumn{5}{|c|}{ Magnitude } \\
\hline 1 & $\begin{array}{l}\text { Confidence in overcoming the difficulties of } \\
\text { developing entrepreneurship }\end{array}$ & 186 & 4,65 & Very High \\
\hline 2 & $\begin{array}{l}\text { Not easy to give up if the business is less } \\
\text { Desirable }\end{array}$ & 190 & 4,75 & Very High \\
\hline 3 & $\begin{array}{l}\text { Be more vigilant in moving if there is a failure } \\
\text { in people who are entrepreneurs }\end{array}$ & 189 & 4,72 & Very High \\
\hline 4 & $\begin{array}{l}\text { Enrich yourself about the ins and outs of } \\
\text { entrepreneurship from books, the experiences } \\
\text { of others, and other sources }\end{array}$ & 185 & 4,62 & Very High \\
\hline \multicolumn{5}{|c|}{ Strength } \\
\hline \multicolumn{5}{|c|}{ Generality } \\
\hline 1 & Enthusiastic in facing challenges in business & 190 & 4,75 & Very High \\
\hline 2 & $\begin{array}{l}\text { Optimistic entrepreneurship after seeing a lot } \\
\text { of successful businesses }\end{array}$ & 195 & 4,87 & Very High \\
\hline 3 & $\begin{array}{l}\text { The belief that entrepreneurial success does } \\
\text { not emerge suddenly, but requires a process }\end{array}$ & 198 & 4,95 & Very High \\
\hline 4 & $\begin{array}{l}\text { Getting what you want as long as it's } \\
\text { accompanied by hard work }\end{array}$ & 193 & 4,82 & Very High \\
\hline & \multicolumn{2}{|c|}{ Average } & 4,84 & Very High \\
\hline 1 & $\begin{array}{l}\text { Not affected when offered another more } \\
\text { lucrative business }\end{array}$ & 180 & 4,5 & Very High \\
\hline 2 & $\begin{array}{l}\text { Work harder if you have not reached the } \\
\text { Target }\end{array}$ & 184 & 4,6 & Very High \\
\hline 3 & Trying to evaluate yourself to be better & 172 & 4,3 & Very High \\
\hline 4 & Luck will take sides if done well & 192 & 4,8 & Very High \\
\hline
\end{tabular}

* Corresponding author's e-mail: kania.ratnasari@yahoo.com 


\begin{tabular}{|c|c|c|}
\hline Average & $\mathbf{4 , 5 5}$ & Very High \\
\hline Total Average & $\mathbf{4 , 6 9}$ & Very High \\
\hline
\end{tabular}

Source: Data Processed (2020)

Based on table 3 it can be seen that the Strength indicator obtains the highest average value of 4.84 with a very high category. Followed next by the Magnitude indicator of 4.68 with a very high category, then the indicator with the lowest average value, namely Generality with a mean value of 4.55 , including the very high category. Based on the overall indicators of self efficacy obtained a value of 4.69 with a very high category. For a more detailed discussion, we will describe each of the following selfefficacy indicators.

\section{Magnitude}

Descriptive analysis results in table 4, the magnitude indicator shows the average value of 4.68 , including the second highest indicator. The highest statement is about not giving up easily if the business is less desirable with an average value of 4.75 and the lowest statement is about enriching yourself about the ins and outs of entrepreneurship from books, experiences of others, and other sources with an average value of 4,62. The results of this study indicate that based on the level of difficulty (magnitude) in carrying out a task or job, the entrepreneurs in Harapan Island have a high optimistic view, do not easily give up and feel challenged by the difficult task so that it can be used as a learning process,

\section{Strength}

Descriptive analysis results in table 5, namely the strength indicator shows the average value of 4.84 including the first highest indicator. The highest statement is about the belief that entrepreneurial success does not emerge suddenly, but it requires a process with an average value of 4.95 while the lowest statement is about being enthusiastic in facing challenges in business with an average value of 4.75 . The results of this study indicate that, entrepreneurs in Harapan Island have strong self-efficacy, believe that success and success must be carried out through the process and they will be ready to face if they experience failure in entrepreneurship.

\section{Generality}

The results of the descriptive analysis in table 6, the generality indicator shows the average value of 4.55 , including the lowest indicator. The highest statement that is about luck will take sides if done well with an average value of 4.8 and the lowest statement is about trying to evaluate themselves to be better with an average value of 4.30 .

The results of this study indicate that the entrepreneurs in Harapan Island have a good mind that if they do their job properly and correctly, luck can become their own.

\section{CONCLUSION}

The overall entrepreneurial characteristics included in the high category with the highest indicator, Need for Achievement and the lowest indicator, Propensity to Take Risk. The highest outcome of the entrepreneurial characteristic variable is the Need for Achievement which means that the residents of Harapan Island, which are used as research samples, have a preference for challenging tasks where they require skill and effort, and can provide clear feedback on work results. those where the situation is very closely related to entrepreneurial activities. Respondents with a high need for achievement have a strong desire to succeed as an entrepreneur.

Meanwhile, the lowest yield of the entrepreneurial characteristic variable is 
Propensity to Take Risk. This reflects how a person behaves in facing a risky situation, where the situation can have a high level of uncertainty and the possibility of loss. This turned out to be still low, it could be due to the unpreparedness of the entrepreneurs when experiencing losses in entrepreneurship, for that they sometimes choose to minimize or even reject all forms that have a high-risk tendency.

As for overall self-efficacy, it is categorized as very high with the highest indicator being Strength and the lowest indicator being Generality. For selfefficacy variables, the highest category is Strength. This aspect relates to the level of strength of an individual's beliefs or expectations regarding his abilities. This category reflects the resilience and perseverance of a person in entrepreneurship. This category is the highest, meaning that respondents have high confidence that they have hardiness, perseverance and tenacity in entrepreneurship.

As for the self-efficacy variable, the lowest category is Generality. Selfefficacy for this Generality concept is not limited to certain situations and conditions. Conditions where a person is sure to be capable and has ability in many fields or business activities. In this study, the Generality category is low. This means that respondents assess their confidence to be able to carry out certain activities only under certain conditions. So, they cannot do a task with several or many aspects at once.

\section{REFERENCES}

Ardiansyah, A. (2017). PENGARUH

KARAKTERISTIK

KEWIRAUSAHAAN TERHADAP

KEBERHASILAN USAHA PADA

PARA PELAKU USAHA KULINER

DI SEPUTARAN UNIVERSITAS
MULAWARMAN SAMARINDA.

5(3), 626-637.

Ghina, A., \& Ramadhan, F. (2017). ANALISIS KARAKTERISTIK

KEWIRAUSAHAAN DAN MINAT

KEWIRAUSAHAAN PADA

MAHASISWA FAKULTAS

INDUSTRI KREATIF

UNIVERSITAS TELKOM

ANGKATAN 2012-2013. 4(3), 2172-2179.

Isa, M. (2011). Analisis Kompetensi

Kewirausahaan, Orientasi

Kewirausahaan, Dan Kinerja

Industri Mebel. Analisis

Kompetensi Kewirausahaan

BENEFIT Jurnal Manajemen Dan

Bisnis, 15(2), 159-168.

Kerr, S. P., Kerr, W. R., \& Xu, T. (2018). Personality traits of entrepreneurs: A review of recent literature. In Foundations and Trends in Entrepreneurship (Vol. 14, Issue $3)$.

https://doi.org/10.1561/030000008 0

Kraus, S., Rigtering, J. P. C., Hughes, M., \& Hosman, V. (2012). Entrepreneurial orientation and the business performance of SMEs: A quantitative study from the Netherlands. Review of Managerial Science, 6(2), 161-182. https://doi.org/10.1007/s11846011-0062-9

Newman, A., Obschonka, M., Schwarz, S., Cohen, M., \& Nielsen, I. (2019). Entrepreneurial self-efficacy: A systematic review of the literature on its theoretical foundations, measurement, antecedents, and outcomes, and an agenda for future research. Journal of Vocational Behavior, 110(October 2017), 403419. https://doi.org/10.1016/j.jvb.2018. 05.012 